\title{
Reducing gender bias in STEM
}

\author{
Stephanie Mabel Kong ${ }^{1, *}$, Katherine Margaret Carroll ${ }^{2}$, Daniel James Lundberg ${ }^{1}$, Paige Omura ${ }^{1}$ and Bianca Arielle Lepe ${ }^{3}$ \\ Edited by Friederike M. C. Benning and Anthony Tabet
}

\section{HIGHLIGHTS}

- Gender discrimination continues to persist in STEM disciplines.

- Federal, state, and local institutions can take steps to promote STEM role models, extracurricular enrichment and provide clear, progressive laws on gender discrimination, pay transparency and parental leave.

- Institutions can enact policies to improve workplace diversity and job accessibility by systematically addressing gender biases and providing better metrics for assessing gender equity.

Women continue to be underrepresented in science, technology, engineering, and math (STEM). Gender discrimination and gender bias reinforce cultural stereotypes about women and their ability to perform in male-dominated STEM fields. Greater policy intervention can bolster national response to gender-based harassment and discrimination. There are four major efforts that individual institutions, local governments, and the federal government can support to combat gender discrimination in STEM: (1) invest in early education initiatives for increasing female representation, (2) institute stronger state and federal policies around gender discrimination, (3) foster workplace practices that promote diversity, and (4) develop better quantification and metrics for assessing gender discrimination to enact more meaningful policies.

G ender discrimination is unfavorable treatment on the basis of gender. In the United States, the Civil Rights Act of 1964 outlawed gender discrimination in hiring, firing, pay, job assignments, promotions, as well as sexual harassment [1]. But if history is any indication, ensuring non-discriminatory workplace policies and practices is a slow process. Discriminatory practices are rooted in larger cultural and social norms, and the definition of gender discrimination

\footnotetext{
${ }^{1}$ Department of Chemical Engineering, Massachusetts Institute of Technology, Cambridge, MA

${ }^{2}$ Department of Aeronautics and Astronautics, Massachusetts Institute of Technology, Cambridge, MA

${ }^{3}$ Department of Biological Engineering, Massachusetts Institute of Technology, Cambridge, MA

*Email: kong94@mit.edu
}

The authors declare no conflict of interest.

(C) 2020 The Author(s) is continually evolving. While the topics discussed herein may also apply to other forms of discrimination, the authors have chosen to focus on gender discrimination as it relates to women in science, technology, engineering, and math (STEM).

\section{Gender equity is a problem in STEM}

\section{Gender disparity by the numbers}

The percentage of women earning degrees in STEM fields illustrates the gender disparity within the United States. With the exception of the life sciences, women are underrepresented across all STEM fields [2]. Between 2008-2015, women earned $35.1 \%$ and $34.5 \%$ of undergraduate and PhD STEM degrees, respectively [3]. In 2016 , women only made up $20.1 \%$ of computer science doctoral degree conferrals [4]. Further, fewer women occupy senior positions within STEM. In 2008, women only held a quarter of full-time junior faculty positions in engineering [5]. Women leave academia at a much higher rate than men, due in part to persistent gender biases [6,7]. In hiring, for example, science faculty are found to rate identical resumes with male names higher than those with female names, and were willing to offer higher salaries to the male applicant [8].

This bias extends to industry as well. Women make up slightly less than a quarter of those employed, with particular underrepresentation in engineering and computer jobs $[9,10]$. Women are also $30 \%$ less likely to be called to interview for a job than an equally qualified male counterpart [11]. Once hired, men are promoted at a $30 \%$ higher rate than women. This leads to female underrepresentation in higher-paying and higher-ranked roles in business [12]. Other reasons for increased attrition of women in academia include disparities in funding support and salary [5].

\section{Gender discrimination from inequitable system design}

Current social, workforce, political, healthcare, and technical systems favor men [13]. The emergence of such bias is the result of two key, erroneous assumptions: (1) standards designed for men apply equivalently to women and (2) systems do not need to be re-designed for women.

Standards that apply equally for men and women produce inequitable, and often, unsafe outcomes for women. The crash test dummy is designed for the 50th percentile male. This standard results in women being $47 \%$ more likely to be seriously injured and $71 \%$ more likely to be moderately injured 
in a car crash when compared to male drivers [14]. In a 2016 survey on the lack of Personal Protective Equipment (PPE) designed for women, $57 \%$ of the female participants reported that PPE "sometimes or significantly" hampers their ability to do their job [15]. The general presumptions of equitable baselines have posed unfair and, in many cases, unsafe conditions for women.

Although the systems designed for men have not changed, the environment and people that those systems serve, have. The current standard office temperature was designed in the 1960 s to support the resting metabolic rate of an average forty-year-old, $70 \mathrm{~kg}$ male, overestimating the metabolic rate of women by as much as $35 \%$ [16]. This correlates to a recommended temperature increase for women between 2 to 4 degrees Fahrenheit [17]. A 2019 study found that women perform better at higher temperatures, suggesting that workplaces with both men and women may increase their productivity by raising the temperature [18]. The fact that the changing workplace demands of the 21 st-century have largely gone unnoticed reflects a greater need to re-adjust systems that now serve large populations of both men and women.

\section{So what can we do about it?}

\section{Start Early}

Ever since the 1970s, the U.S. has supported policies to help protect and promote the education of women, including Title IX of the Education Amendments Act of 1972 and the Women's Educational Equity Act (WEEA) in 1974 [19]. However, women still remain underrepresented in many disciplines in the U.S. Female under-representation in STEM begins in early childhood. A poll of over $200 \mathrm{New}$ York kindergarten students found that a gender-brilliance stereotype exists as early as the age of six years old, where the characteristic of being "really, really smart" is associated more with white men than white women [20]. It is much harder to correct for this gender-brilliance bias once it has already been taught [13]. Early education initiatives intended to break down gendered stereotypes about who is "smart" or "good" at science are likely to be more effective with early elementary and even pre-K students. (1) Establishing diverse role models to promote diversity in STEM fields and (2) supporting extracurricular STEM programs are two techniques for preventing women from opting out of joining the STEM workforce at a higher rate than men.

\section{Diverse role models promote diversity in STEM fields}

The inclusion of diverse STEM role models in common media outlets promotes diversity in STEM fields and fosters a positive association of women and STEM from an early age and onwards. In film, men are depicted in STEM professions at five times the rate at which women are depicted. In family films, men are 14 times more likely to be depicted in STEM professions than women [21]. Classrooms, the media, and popular culture are avenues through which this bias can be checked. A 2016 report from the Obama White House highlighted three ways in which the entertainment industry can increase diverse STEM content: (1) increasing the representation of STEM professionals, (2) emphasizing the variety of STEM occupations, and (3) discrediting existing STEM misconceptions [21]. There is positive evidence to support that this approach is effective. For example, a recent study found that female 9th and 10th grade students perform better in science when the images in their textbooks include counter-stereotypic images of female scientists [22]. Another study found that exposure to non-stereotypical role models increased the self-efficacy of female computer scientists [23]. Given that these disparities in diverse STEM representation still persist, there has not been enough political response and accountability measures to these findings.

\section{Extracurricular STEM programs lead to higher numbers of women majoring in STEM disciplines}

Supporting a variety of STEM-related extracurricular activities is an effective way of attracting and retaining women to STEM disciplines [24].

There is a significant drop in computer science interest as girls age. Girls Who Code, an extracurricular program with a computer science focus for girls interested in programming, reports that interest reduces from $66 \%$ to merely $4 \%$ in girls between the ages of six to eighteen, respectively [25]. By offering year-long clubs, after-school activities, and summer immersion programs, participants of Girls Who Code study computer science in college at "15 to 16 times the national average" [26].

FIRST (For Inspiration and Recognition of Science and Technology) is a research and robotics community open to students from kindergarten through grade 12 [27]. FIRST competitions and challenges focus on current problems facing the STEM community. While estimates from a 2016 National Science Board report indicate that $13.7 \%$ of men and $2.6 \%$ of women entering college intend to major in engineering [28], male and female alumni of FIRST programs intend to major in engineering at a rate of $67 \%$ and $47 \%$, respectively [29]. These after-school programs aid in the retention of students who are interested in engineering by maintaining interest through the time they enter college.

An important aspect of drawing more women to STEM is letting them know that they belong. Empowering young women to get involved in current "real-world" issues, like climate action, poverty, or sustainability, is a big part. Pretty Brainy, a program developed by the Women's Foundation of Colorado, uses a methodology called design thinking to capture students' interest to serve their communities and develop authentic solutions [30]. The results of this methodology are encouraging. According to a survey by Pretty Brainy in 2018, the program led to an increased interest in innovation and design in $100 \%$ of the surveyed girls. A stronger interest in science and technology as a direct consequence by the program was reported by $92 \%$ of surveyed girls [31].

After school STEM curricula have been effective in generating 
STEM interest. A recent analysis of 160 afterschool STEM programs across 11 states found that $80 \%$ of the participating students reported an increase in their science career knowledge and $73 \%$ reported an increase in their "science identity" - a personal belief that the student can succeed at science [32]. These results demonstrate the tangible importance that STEM-focused extracurricular programs can bring to advancing the STEM pathway. Gilbert et al. suggests that "for every child enrolled in an afterschool program today, there are two children who would be enrolled if an opportunity were available and affordable" [33]. Greater accessibility to these programs for marginalized groups is a critical part of creating a diverse STEM workforce.

Reform state and federal laws on gender discrimination pay transparency and parental leave

Although gender discrimination was declared illegal by the federal government, acts of gender discrimination often fall into a gray area in practice [34]. What constitutes unlawful discrimination is often determined on a case-by-case basis in state courts. Policymakers can aid by (1) providing nuanced definitions for sex-based discrimination at the federal and state level, (2) requiring pay equity transparency from employers and (3) adopting a standard parental leave policy.

\section{Detailed definitions for sex-based gender discrimination promotes the elimination of biased workplace policies}

The scope and depth of gender discrimination laws vary widely by state. California has adopted clear guidance, with separate definitions for sex and gender discrimination, and explicit examples of discriminatory actions in the workplace. Given that women are often more likely to volunteer for non-promotable tasks [35], California legislature now requires employers to factor both paid and unpaid (voluntary) work into promotions [34]. Many states only prohibit "sex and gender discrimination" - without defining what constitutes sex and gender discrimination. Virginia only outlaws gender discrimination for businesses above a certain size. Alabama has no state laws on sex and gender discrimination. In addition, most states permit some level of gender discrimination in occupations where sex is "required by business necessity" [36]; but well over half do not define what qualifies as a "business necessity" - leaving it subject to employer interpretation. This has been a controversial topic for several sectors where sex or gender can be considered a bona fide occupational qualification (BFOQ), e.g. the sex industry, military, and law enforcement [36]-[39].

Allowing employer interpretation of these policies has consequences. Companies have refused to provide workplace accommodations to pregnant women working jobs that require strenuous labor, despite providing such accommodations to employees with other medical needs [40]. Additionally, these discrimination cases disproportionately affect women of color, and black women in particular - who make up $14 \%$ of the female labor force, but represented $28.6 \%$ of the charges of pregnancy discrimination filed with the EEOC between 2011-2015 [41]. These cases continue to occur despite the
Pregnancy Discrimination Act of 1978 [42], indicating that employers rarely understand what responsibilities they have in ensuring non-discriminatory workplace policies.

In STEM, gender discrimination is just as rampant. Grant eligibility is often determined from years since receiving a $\mathrm{PhD}$ degree, but that grant schedule rarely accounts for time off on maternity leave [43]. Pregnant graduate students and postdocs often face blatant discrimination from their professors, who hold the power to cut funding and jobs if having a child is viewed as "slacking off" [44]. While universities have Title IX offices to protect the victim in such cases, these university offices and programs can only go so far if those in power do not interpret such actions as discrimination.

Nuance in the law can help institutions and employers understand and eliminate policies that lead to gender discrimination. As an institutional example, the Office of Civil Rights (OCR) can work with colleges and universities to develop better procedures for enforcing Title IX policies [45]. When the law is less subject to interpretation, fair treatment is enforceable. However, while clearer definitions can lend guidance to how society identifies discriminatory actions, laws that are too specific run the risk of failing to cover all cases of gender discrimination and limiting the powers of the courts. It is important that laws strike a delicate balance between providing clear, actionable guidance and ensuring that the courts have the freedom to continually refine such definitions, based on case-specific circumstances.

\section{Legislative action for pay equity transparency narrows the gender wage gap}

In STEM, the gender pay gap is nuanced. The gender pay gap is smallest in life science disciplines and largest in computer science and engineering. A recent Bloomberg report on the best paid jobs in STEM calculate that female computer systems analysts and electrical engineers earn 85 cents for every dollar men earn [46]. These gaps persist even after controlling for demographic variables (e.g. race, family, seniority) [47].

Countries around the world are taking action. However, creating effective policies relies on accurate, representative data. Acquiring such data is challenging - especially from private companies. To address this, many countries require private companies to make pay data public. Since 2017, all large UK companies must publish mean and median hourly wages, all bonuses, as well as the proportion of males and females receiving bonuses and the proportion of males and females in each pay quartile [48, 49]. German companies with more than 500 employees must publish regular reports on gender parity [50]. Companies in Iceland must prove that they provide equal pay to their employees [51], and are externally audited [52]. This is all in stark contrast to the U.S. The Equal Employment Opportunity Commission (EEOC) will soon cease collecting wage data after complying with the two-year federal court order to obtain these figures [53]-[55]. Studies on the gender wage gap in STEM primarily rely on 
sample surveys and smaller pools of respondents. It can be challenging to gain population-level statistics for implementing nation-wide policies without census-level reporting of pay data.

Salary transparency is the first step in understanding how to best implement policy [56]. Without pay transparency, it is impossible to conduct the meta-analyses required for effective policy efforts.

\section{Mandated parental leave shifts cultural stereotypes about hiring and promoting women}

It is no secret that having a family disproportionately affects women. According to a 2010 survey of STEM careers, only $57 \%$ of new mothers worked full time, compared to $78 \%$ of new fathers [57]. Still, the U.S. has very few federal laws to protect the careers of women in STEM. The U.S. lags behind when it comes to federally mandated paid maternity leave. Out of the 36 member nations comprising the Organization for Economic Co-operation and Development (OECD), the U.S. is the only nation that does not provide government-mandated maternity leave [58]. Mandated maternity leave can ensure uniformity in workplace policies around pregnancy and paid leave.

Maternity leave alone can reinforce gender stereotypes about a woman's responsibility to do the majority of child-rearing [59]. Moreover, women who take longer maternity leaves are less likely to be promoted or receive pay raises - leading to stalled career growth. In order to ensure that not all of the burden for child care falls on the mother, 24 countries in the OECD provide paid paternity leave. In recent years, states like California, New York, New Jersey, and Rhode Island have provided publicly-funded paid parental leave [60].

Paid parental leave can aid in reducing the cultural stigma associated with hiring women. Many women who work often take on the additional role of rearing children. This can lead to gender discrimination at work in project assignments and promotions if supervisors feel the need to assign smaller roles to women with families. In addition, studies indicate that even if a working mother is the household's sole breadwinner, and child-rearing duties are shared equally between both parents, social norms around her implied duties and additional responsibilities as a being mother may prevent her from being seen as equally capable to her male colleagues [61,62]. As some scholars have noted, "gender equality is slowed to the extent that efforts are focused exclusively on women" [63]. If both men and women are held responsible for taking time off to care for children, it is likely that cultural stereotypes will shift.

\section{Build better workplace cultures}

Although women have begun to move into traditionally male domains, gendered expectations and stereotypes remain. By taking a top-down, system-wide approach to combating divisive stereotypes, academic and corporate leadership can lay a strong foundation for workplace diversity and inclusion.

Gender neutral hiring processes ensure unbiased hiring

\section{processes}

Decades of research have shown that people have a bias towards preserving the status quo. Researchers at the University of Colorado's Leeds School of Business tested the strength of biases by examining the effect of gender, which was implied via manipulation of candidate names, on a candidate's likelihood of being hired from a four-candidate finalist pool. Where there were two men and two women in the pool, the likelihood of hiring a woman was $50 \%$. However, when there was only one woman and three men, the likelihood of hiring a woman dropped to $0 \%$, suggesting that if a candidate pool is even slightly more male, employers are extremely unlikely to select a female [64].

Gender-blind hiring policies and technology that aids in removing gender from the application can help remove bias against female candidates. GapJumpers is a software platform that conducts tailored technical screens of job applicants prior to showing the employer any biographical information. Only after the employer selects candidates to interview based off of their test score will the employer see names and resumes [65]. For companies that do not have the budget for paid options like GapJumpers, there are custom alternatives to achieve gender-blind hiring. The American Alliance of Museums, a non-profit with 40 employees in Virginia, explicitly told candidates not to include their name, address, college name, or graduation date on their resume. Each resume is assigned a number, and applicants are referred to by their number until invited for in-person interviews. Candidates who send in resumes with identifying information are simply not considered [66].

\section{Mentorship and targeted training programs facilitate promotion of women to executive positions}

The corporate funnel to top executive positions is not conducive to promotion of diverse candidates, as women lag behind men at various management levels. Based on five years of data across more than 300 organizations, McKinsey and Leanln.Org's Women in the Workplace 2019 report found that significantly more men than women are promoted to the position of first-level manager. Only 72 women to every 100 men are promoted (or externally hired) to become a manager for the first time $[12,67]$. To combat this systemic barrier, mentorship programs that connect minorities with experienced managers or role models as well as clearly articulated promotion criteria can help prepare potential managers and level the playing field

The gender biases continue higher up the ladder, as the corporate funnel does not enable minorities to pursue C-suite positions. As of December 2019, despite the fact that $50 \%$ of American jobs belong to women [68], only $6.6 \%$ of Fortune 500 CEOs are women [69]. A Wall Street Journal study of executives at the largest publicly traded firms by market value shows that "line roles," which are roles with profit-and-loss responsibilities, are what set executives on the CEO track. Men dominate roles with these responsibilities, such as heading a division, unit or brand. Conversely, women often 
lead divisions like human resources, administration or legal - all of which have no profit-and-loss associated with them [70]. Providing women and men alike with training, preparation for, and exposure to roles with profit-and-loss responsibilities can additionally increase the likelihood of promotion to CEO later in one's career.

Sanofi SA is one example of a STEM company that collected and examined its internal data to identify gender discrepancies, implemented a women-focused management trainee program, and has seen quantifiable results from that program. In 2012, Sanofi looked at the gender breakdown of its internal "talent pipeline" and discovered that the percentage of women in management roles dropped at every level, with the steepest "drop-off [...] just below the senior-leadership level" [70]. To combat this discrepancy in female representation in senior leadership, Sanofi implemented a six-month leadership program in which $30+$ women per year receive executive coaching and a high-responsibility project outside of their primary business area. Since the global launch of Sanofi's program in 2018, one-third of the 92 program participants were promoted. Additionally, women now lead all five of Sanofi's North America businesses, which were previously run by five men $[70,71]$.

A critical piece in ensuring actionable insights is the continued collection and reporting of gender data at each management level. With a more complete dataset, gender breakdown at each management level could be further correlated with financial performance and analyzed (1) within a given corporation, (2) across similar/rival corporations, and (3) across various fields and industries.

\section{Accommodating flexible working arrangements and modeling healthy work-life balance reduces "motherhood bias"}

Women make up the minority of employees in the tech industry and the responsibilities of parenthood fall disproportionately on them. Women often encounter a "maternal wall bias," in which "colleagues view mothers - or pregnant women - as less competent and less committed to their jobs" [61,72]. Existing gender stereotypes make women vulnerable to being seen as less effective if a company has a "workaholic" culture that rewards face time over performance.

Employers can reduce stigma for working mothers by normalizing regular or flexible work hours for all employees. Managers themselves can embrace normal work hours and encourage their team to follow suit. If a male manager says he is leaving exactly at $5 \mathrm{pm}$ to pick up his children from school, his colleagues, male and female, may feel more comfortable leaving the office the next time they have family priorities. Schedule flexibility does not mean employees must work less; an employer could implement a set 40-hour work week yet allow for daily flextime. For example, an employee could start work at 7 am to leave by $3 \mathrm{pm}$ for familial or other duties [73].

Ultimately, responsibility falls on corporate leadership to implement policies that combat gender discrimination. However, every individual can help build a healthy workplace environment by actively encouraging flexible work. Individuals will have varied professional and personal priorities at different stages of their careers, so work-life flexibility can provide benefits across the board, while mitigating negative stigma that disproportionately affects working women.

\section{Drive policy decisions with data}

Quantifying gender discrimination is necessary for effective policy design. Data-driven analysis of policies to improve gender discrimination can validate an approach and facilitate wider implementation. Conversely, when a policy does not have the desired outcome, adequate data collection can help policymakers improve their strategy in an informed way. Through (1) mandated collection and reporting of this data, and (2) using this data to evaluate and hold institutions accountable for their behavior, gender discrimination can be more fully understood and reduced.

\section{Mandated collection and reporting of gender specific} data increases awareness of gender diversity

Aiming to increase corporate accountability and awareness about gender representation and diversity, the Bloomberg Gender-Equality Index tracks public companies who are "committed to supporting gender equality through policy development, representation, and transparency" [74]. The index presents a standardized reporting framework and tracks companies and organizations in STEM and beyond measuring how they promote gender equality across five dimensions: (1) female leadership and talent pipeline, (2) equal pay and gender pay parity, (3) inclusive culture, (4) sexual harassment policies, and (5) pro-women brand [75]. The collection and public presentation of this data provides power to current and future members of the U.S. workforce to make informed decisions and puts societal pressure on corporations to reduce gender discrimination within their organizations.

Collecting sex-disaggregated data is also essential for protecting women's health. During the 2002-2004 SARS outbreak in China, pregnancy was treated like any other condition and was not systematically tracked, thus hampering the later understanding of the World Health Organization on the clinical manifestations of pregnancies complicated by SARS [76]. An early analysis of sex-disaggregated data for the COVID-19 pandemic suggests that there are gendered differences in disease diagnosis, mortality and vulnerability [77]. Many factors that contribute to the "differential vulnerability" that women and men experience reveal the importance of sex-disaggregated data collection [78].

\section{Developing metrics reinforces organizational accountability to reduce gender discrimination}

A number of international metrics to measure gender equity currently exist. The Gender Empowerment Measure (GEM) measures the equity of opportunities afforded to men and women. The Gender Equity Index (GEI) is used by 
the European Union to measure gender equity related to work, money, knowledge, time, power and health of their member states. Such metrics provide a high-level overview of gender equity. In comparison, the Athena SWAN award of the United Kingdom is an example of a national metric already finding use in helping promote women's status in science. The award, which serves as an institutional report card recognizing good practices in recruiting, retaining, and promoting women in scientific fields, can be used to inform and aid other organizations in proving gender parity and reducing gender discrimination [79]. Organizations that wish to apply need to sign a charter stating their commitment to advancing the careers of women, and specifically reducing underrepresentation and the pay gap. Institutions which participated in the program saw more equal workloads between men and women, as well as an increase in women's confidence and leadership [80].

Taking inspiration from the Athena SWAN award, the New York Stem Cell Foundation (NYSCF) convened a working group for the Initiative on Women in Science and Engineering (IWISE) that proposed "seven actionable strategies for advancing women in STEM" [81]. One of the strategies was creating an institutional gender equality report card that would enable the quantification of gender disparity and the degree to which policies and interventions are effective in reducing such disparities [82]. The report card was piloted over four years, during which NYSCF obtained data from more than 500 institutions across 38 countries. In an effort to evaluate the effectiveness of gender equity policy interventions, the report card combines qualitative assessments of institutional initiatives intended to support women with statistics on gender representation in academia. Subsequent analysis of the data highlighted several trends; gender representation decreased as seniority increased; women had low representation in seminar-speaker and influential committee roles [82]. A second phase of this initiative will commence to share learnings from high-scoring institutions.

The collection and reporting of data and the establishment of clearly defined and actionable metrics facilitate the formulation of effective gender discrimination policies. However, it is important to avoid several pitfalls: First, responsibility for adhesion to the standards should be shared equally — as gender equity work often falls disproportionately on women [81]. Second, such standards should introduce flexibility, as seen with the Athena SWAN award, which encourages adoption by allowing all levels to make meaningful change. Last, information collected by any source should be shared widely and publicly, allowing those who make policy to have the most complete understanding of the situations they are aiming to rectify.

\section{Conclusions}

The disproportionately lower representation of women in STEM fields is a reflection of underlying issues rooted in gender bias and discrimination. While we've increased representation in certain STEM fields, not all sectors have seen similar successes. Even when gender parity is reached within a field, there are still stark differences in the gender makeup of senior leadership. Without intervention and active discussion, STEM will continue to perpetuate the same biases that reinforce gender stereotypes. Our current environment from early education to adulthood - is not set up to afford women equitable opportunities to succeed in male-dominated STEM careers. Accordingly, changing this dynamic will require concerted effort and engagement from many parties on multiple fronts: early education initiatives to promote diversity in STEM, state and federal legislation to guide institutional policies on wages and parental leave, inclusive workplace cultures to foster mentorship and encourage work-life balance, and collection of gender-specific data and metrics of accountability to create data-driven policy decisions.

\section{Citation}

Kong, S. M., Carroll K. M., Lundberg, D. J., Omura, P. \& Lepe, B. A. Reducing gender bias in STEM. MIT Science Policy Review 1, 55-63 (2020).

\section{Open Access}

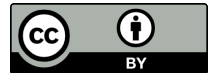

This MIT Science Policy Review article is licensed under a Creative Commons Attribution 4.0 International License, which permits use, sharing, adaptation, distribution and reproduction in any medium or format, as long as you give appropriate credit to the original author(s) and the source, provide a link to the Creative Commons license, and indicate if changes were made. The images or other third party material in this article are included in the article's Creative Commons license, unless indicated otherwise in a credit line to the material. If material is not included in the article's Creative Commons license and your intended use is not permitted by statutory regulation or exceeds the permitted use, you will need to obtain permission directly from the copyright holder. To view a copy of this license, visit http://creativecommons.org/licenses/ by $/ 4.0 /$.

\section{References}

[1] Civil Rights Act of 1964. URL https://www.eeoc. gov/statutes/title-vii-civil-rights-act-1964. Accessed June 2020.

[2] Falkenheim, J. C. Higher education in science and engineering. Report, National Science Board (2018). URL https: / / www . nsf.gov/statistics/indicators/. Accessed June 2020.

[3] Table 318.45: Number and percentage distribution of science, technology, engineering, and mathematics (STEM) degrees/certificates conferred by postsecondary institutions, by race/ethnicity, level of degree/certificate, and sex of student: 2008-09 through 2014-15. U.S. Department of Education, National Center for Education Statistics, Integrated Postsecondary Education Data System (IPEDS). (2016). URL https://nces.ed.gov/programs/digest/d16/tables/ dt16_318.45.asp. Accessed June 2020

[4] Quick take: Women in science, technology, engineering, and mathematics. Catalyst (2019). URL https: //www.catalyst.org/research/women-in-sciencetechnology-engineering-and-mathematics-stem/. Accessed June 2020.

[5] Shen, H. Inequality quantified: Mind the gender gap. Nature 495, 22-4 (2013). https://doi.org/10.1038/495022a. 
[6] Dasgupta, S. Inadequate representation of women in STEM research: The "leaky pipeline". Editage Insights (2017). URL https://www.editage.com/insights/ inadequate-representation-of-women-in-stemresearch-the-leaky-pipeline. Accessed June 2020, https://doi.org/10.34193/EI-A-5452.

[7] Rice, C. Why women leave academia. Inside Higher Education (2012). URL https://www.insidehighered.com/blogs/ university-venus/why-women-leave-academia. Accessed June 2020

[8] Moss-Racusin, C. A., Dovidio, J. F., Brescoll, V. L., Graham, M. J. \& Handelsman, J. Science faculty's subtle gender biases favor male students. Proceedings of the National Academy of Sciences 109, 16474-16479. https://doi.org/10.1073/ pnas. 1211286109.

[9] Noonan, R. Women in STEM: 2017 update. U.S. Department of Commerce (2017). URL https://www.commerce. gov/news/fact-sheets/2017/11/women-stem-2017update. Accessed June 2020.

[10] Landivar, L. C. Disparities in STEM employment by sex, race, and hispanic origin. U.S. Department of Commerce (2013). URL https://www2.census.gov/library/publications/ 2013/acs/acs-24.pdf. Accessed June 2020.

[11] González, M. J., Cortina, C. \& Rodríguez, J. The role of gender stereotypes in hiring: A field experiment. European Sociological Review 35, 187-204 (2019). https://doi.org/10.1093/ esr/jcy055.

[12] Werber, C. McKinsey and Lean In say they've found the biggest barrier to gender parity at companies. Quartz at Work (2019). URL https://qz.com/work/1728182/mckinsey-andlean-in-women-are-less-likely-to-be-promotedor-hired-to-first-time-manager/. Accessed June 2020.

[13] Criado Perez, C. Invisible Women: Data Bias in a World Designed for Men (Abrams Press, New York, 2019).

[14] Shaver, K. Female dummy makes her mark on male-dominated crash tests. Washington Post (2012). URL https://www. washingtonpost.com/local/trafficandcommuting/ female-dummy-makes-her-mark-on-male-dominatedcrash-tests/2012/03/07/gIQANBLjas_story.html. Accessed June 2020.

[15] Trades Union Congress. Personal protective equipment and women (2017). URL https://www.tuc.org.uk/sites/ default/files/PPEandwomenguidance.pdf. Accessed June 2020.

[16] Kingma, B. \& van Marken Lichtenbelt, W. Energy consumption in buildings and female thermal demand. Nature Climate Change 5, 1054-1056 (2015). https://doi.org/10.1038/ nclimate 2741.

[17] Watson, T. Workplace AC comfy for men - but not women. USA Today (2015). URL https://www.usatoday.com/ story/news/2015/08/04/air-conditioning-womenworkers/31120009/. Accessed June 2020.

[18] Chang, T. Y. \& Kajackaite, A. Battle for the thermostat: Gender and the effect of temperature on cognitive performance. PLOS ONE 14, e0216362 (2019). https://doi.org/10.1371/ journal.pone.0216362.

[19] Madigan, J. C. The education of women and girls in the United States: A historical perspective. Advances in Gender and Education 1, 11-13 (2009). URL https: //www.ncgs.org/wp-content/uploads/2017/11/TheEducation-of-Girls-and-Women-in-the-UnitedStates-A-Historical-Perspective.pdf.

[20] Jaxon, J., Lei, R. F., Shachnai, R., Chestnut, E. K. \& Cimpian, A. The acquisition of gender stereotypes about intellectual ability: Intersections with race. Journal of Social Issues 75, 1192-1215 (2019). https://doi.org/10.1111/josi.12352.

[21] STEM depiction opportunities. Report, Obama White House (2016). URL https://obamawhitehouse. archives.gov/sites/default/files/microsites/ ostp/imageofstemdepictiondoc_02102016_clean.pdf. Accessed June 2020.

[22] Good, J. J., Woodzicka, J. A. \& Wingfield, L. C. The effects of gender stereotypic and counter-stereotypic textbook images on science performance. The Journal of Social Psychology 150, 132-147 (2010). https://doi.org/10. $1080 / 00224540903366552$.

[23] Cheryan, S., Siy, J. O., Vichayapai, M., Drury, B. J. \& Kim, S. Do female and male role models who embody STEM stereotypes hinder women's anticipated success in STEM? Social Psychological and Personality Science 2, 656-664 (2011). https://doi.org/10.1177/1948550611405218.

[24] New formulas for America's workforce: Girls in science and engineering. Publication No. 03-207. Report, National Science Foundation (2003). URL https://www.nsf.gov/pubs/ 2003/nsf03207/start.htm. Accessed June 2020.

[25] Ware, R. Closing the tech gender divide. First Data: Connected 2 (2017). URL https://www.firstdata.com/newsroom/ assets/fd-connected/pdfs/FD_CONNECTED_VOL2_ _Girls_Who_Code.pdf. Accessed June 2020.

[26] Girls Who Code Annual Report 2019. Report, Girls Who Code (2019). URL https://girlswhocode.com/2019report/ \# numbers. Accessed June 2020.

[27] FIRST. Reaching diverse youth in underserved communities. Report (2019). URL https://www.firstinspires.org/ sites/default/files/uploads/resource_library/ impact/edi-impact-flyer.pdf. Accessed June 2020.

[28] National Science Board. Science and Engineering Indicators 2016. NSB-2016-1. Report, National Science Foundation (2016). URL https://www.nsf.gov/statistics/2016/ nsb20161/\#/report/chapter-2/highlights. Accessed June 2020.

[29] Burack, C., Melchior, A. \& Hoover, M. Do after-school robotics programs expand the pipeline into STEM majors in college? Journal of Pre-College Engineering Education Research (J-PEER) 9, 7 (2019). https://doi.org/10. 7771/2157-9288.1244.

[30] García, Y. V., Catchen, R., Cruz, A., Kincaid, P. \& Peters, B. This is what STEM looks like! Report, The Women's Foundation of Colorado (2017). URL https://www.wfco.org/impact/ this-is-what-stem-looks-like. Accessed June 2020.

[31] Pretty Brainy Fact Sheet 2017-2018. Report, Pretty Brainy (2018). URL https://prettybrainy.com/steameducation-outcomes/. Accessed June 2020.

[32] Allen, P. J. et al. Afterschool \& STEM system building evaluation 2016. The PEAR Institute: Partnerships in Education and Resilience, Belmont, MA2017 (2017). URL https://docs.wixstatic.com/ugd/e45463_ e14ee6fac98d405e950c66fe28de9bf8.pdf. Accessed June 2020.

[33] Gilbert, D. et al. Community STEM collaborations that support children and families. Afterschool Alliance (2020). URL https://files.eric.ed.gov/fulltext/ED602091.pdf. Accessed June 2020.

[34] Sex and gender discrimination in the workplace. National Conference of State Legislatures (2019). URL https: //www.ncsl.org/research/labor-and-employment/gender-and-sex-discrimination.aspx. Accessed June 2020.

[35] Babcock, L., Recalde, M. P. \& Vesterlund, L. Why women volunteer for tasks that don't lead to promotions. Harvard Business Review (2018). URL https://hbr.org/2018/07/ why-women-volunteer-for-tasks-that-dont-leadto-promotions. Accessed June 2020.

[36] Hoerner, B. O. The role-modeling BFOQ: Court confusion and education promise. Journal of Business Law 16, 1211 (2014). URL https://scholarship.law.upenn.edu/ cgi/viewcontent.cgi?article $=1458$ \& context=jbl. Accessed June 2020.

[37] Dothard v. Rawlinson, 433 U.S. 321 (1977). 
[38] Hooters settles suit by men denied jobs. New York Times (1997). URL https: //www.nytimes.com/1997/10/01/us/ hooters-settles-suit-by-men-denied-jobs.html. Accessed June 2020.

[39] Aamodt, M. Really, I come here for the food: Sex as a BFOQ for restaurant servers. The Industrial-Organizational Pyschologist 53 (2017). URL https://www.siop.org/ResearchPublications/TIP/TIP-Back-Issues/2017/January/ ArtMID/20301/ArticleID/1624/Really-I-Come-Herefor-The-Food-Sex-as-a-BFOQ-for-RestaurantServer. Accessed June 2020.

[40] Leveille, V. \& Garvey, M. Pregnant workers are still fighting for the right to work. American Civil Liberties Union (2020). URL https://www.aclu.org/news/womensrights/pregnant-workers-are-still-fightingfor-the-right-to-work/. Accessed June 2020.

[41] By the numbers: Women continue to face pregnancy discrimination in the workplace. Data Brief, The National Partnership for Women and Families (2016). URL https: //www. nationalpartnership.org/ourwork/resources/economic-justice/pregnancydiscrimination/by-the-numbers-women-continueto-face-pregnancy-discrimination-in-theworkplace.pdf. Accessed June 2020.

[42] The Pregnancy Discrimination Act of 1978 (1978). URL https://www. eeoc.gov/statutes/pregnancydiscrimination-act-1978. Accessed June 2020.

[43] National Academy of Sciences, National Academy of Engineering, and Institute of Medicine. Biological, Social, and Organizational Components of Success for Women in Academic Science and Engineering: Report of a Workshop. Washington, DC: The National Academies Press (2006). Accessed June 2020, https: / / doi.org/10.17226/11766.

[44] Williams, J. C. \& Massinger, K. How women are harassed out of science. The Atlantic (2016). URL https://www. theatlantic.com/science/archive/2016/07/howwomen-are-harassed-out-of-science/492521/. Accessed June 2020

[45] Lieberwitz, R. et al. The history, uses, and abuses of Title IX. Bulletin, American Association of University Professors (2016). URL https://www.aaup.org/report/historyuses-and-abuses-title-ix. Accessed June 2020.

[46] Busso, M. Women close gender pay gap in two STEM jobs, lag in others. Bloomberg (2017). URL https : / / www . bloomberg . com/graphics/2017-women-stem-jobs/. Accessed June 2020.

[47] Michelmore, K. \& Sassler, S. Explaining the gender wage gap in STEM: Does field sex composition matter? RSF: The Russell Sage Foundation Journal of the Social Sciences 2, 194-215 (2016). http://www.doi.org/10.7758/rsf.2016.2.4. 07.

[48] Alderman, L. Britain aims to close gender pay gap with transparency and shame. New York Times (2018). URL https://www.nytimes.com/2018/04/04/business/ britain-gender-pay-gap.html. Accessed June 2020.

[49] Dromey, L., Joe; Rankin. The fair pay report: How pay transparency can help tackle inequalities. Report, Institute for Public Policy Research (2018). URL https://www.ippr. org/research/publications/the-fair-pay-report. Accessed June 2020.

[50] Oltermann, P. Germany to require firms to publish data on gender pay parity. The Guardian (2016). URL https: //www.theguardian.com/world/2016/oct/ 07/germany-to-require-firms-to-publish-dataon-gender-pay-parity. Accessed June 2020.

[51] Domonoske, C. Companies in Iceland now required to demonstrate they pay men, women fairly. National Public Radio (2018). URL https://www.npr.org/sections/thetwoway/2018/01/03/575403863/companies-in-iceland- now-required-to-demonstrate-they-pay-menwomen-fairly. Accessed June 2020.

[52] Henley, J. 'Equality won't happen by itself': how Iceland got tough on gender pay gap. The Guardian (2018). URL https : / / www. theguardian.com/world/2018/feb/20/icelandequal-pay-law-gender-gap-women-jobs-equality. Accessed June 2020.

[53] Wiessner, D. EEOC will cease collection of pay data under Obama-era rule. Reuters (2019). URL https://www.reuters.com/article/employmenteeoc/eeoc-will-cease-collection-of-pay-dataunder-obama-era-rule-idUSL2N2630VT. Accessed June 2020.

[54] Notice of information collection-request for new control number for a currently approved collection: Employer information report (EEO-1) component 1; revision of existing approval for EEO-1 component 2. (84 FR 48138). Federal Register 84, 48138-48142 (2019). URL https: / / www.federalregister.gov/documents/2019/ 09/12/2019-19767/agency-information-collectionactivities-existing-collection. Accessed June 2020.

[55] ACLU statement on federal agency decision to stop collecting wage data. American Civil Liberties Union (2019). URL https: / / www .aclu.org/press-releases/aclustatement-federal-agency-decision-stopcollecting-wage-data. Accessed June 2020.

[56] Tarr, T. How Icelandic women really feel about the new equal pay law. Forbes (2018). URL https://www. forbes. com/sites/tanyatarr/2018/01/08/how-icelandicwomen-really-feel-about-the-new-equal-paylaw/\#50c027744f13. Accessed June 2020.

[57] Bernstein, R. After a baby, $28 \%$ of new parents leave full-time STEM work. Science (2019). URL https: //wWw.sciencemag.org/careers/2019/02/afterbaby-28-new-parents-leave-full-time-stem-work. Accessed June 2020, http://www.doi.org/10.1126/ science.caredit.aax0346.

[58] OECD family database: Child-related leave. Report, Organisation for Economic Co-operation and Development (2019). URL http://www.oecd.org/els/family/ database.htm. Accessed June 2020.

[59] Hideg, I., Krstic, A., Raymond, T. \& Zarina, T. Do longer maternity leaves hurt women's careers? Harvard Business Review (2018). URL https://hbr.org/2018/09/do-longermaternity-leaves-hurt-womens-careers. Accessed June 2020.

[60] Gupta, V., Hieronimus, S., Krishnan, M. \& Madgavkar, A. Accelerating gender parity: What can governments do? McKinsey \& Company (2019). URL https://www. mckinsey.com/industries/public-sector/ourinsights/accelerating-gender-parity-what-cangovernments-do\#. Accessed June 2020.

[61] Ogden, L. E. Working mothers face a 'wall' of bias-but there are ways to push back. Science (2019). Accessed June 2020, http://www.doi.org/10.1126/science. caredit.aax6510.

[62] Correll, S. J., Benard, S. \& Paik, I. Getting a job: Is there a motherhood penalty? American Journal of Sociology 112, 1297-1339 (2007). https://doi.org/10.1086/511799.

[63] Padavic, I., Ely, R. J. \& Reid, E. M. Explaining the persistence of gender inequality: The work-family narrative as a social defense against the $24 / 7$ work culture. Administrative Science Quarterly 65, 61-111 (2020). https://doi.org/10.1177/ 0001839219832310.

[64] Johnson, S., Hekman, D. \& Chan, E. If there's only one woman in your candidate pool, there's statistically no chance she'll be hired. Harvard Business Review (2016). URL https://hbr.org/amp/2016/04/if-theresonly-one-woman-in-your-candidate-pool-theres- 
statistically-no-chance-shell-be-hired. Accessed June 2020.

[65] Miller, C. C. Is blind hiring the best hiring? The New York Times Magazine (2016). URL https://www. nytimes.com/ 2016/02/28/magazine/is-blind-hiring-the-besthiring.html. Accessed June 2020.

[66] Bortz, D. Can blind hiring improve workplace diversity? Society for Human Resource Management (2018). URL https://www.shrm.org/hr-today/news/hrmagazine/0418/pages/can-blind-hiring-improveworkplace-diversity. aspx. Accessed June 2020.

[67] Huang, J., Krivkovich, A., Starikova, I., Yee, L. \& Zanoschi, D. Women in the workplace 2019. McKinsey \& Company (2019). URL https://www.mckinsey.com/featured-insights/ gender-equality/women-in-the-workplace-2019. Accessed June 2020.

[68] Law, T. Women are now the majority of the U.S. workforce - but working women still face serious challenges. Time (2020). URL https://time.com/5766787/womenworkforce/. Accessed June 2020.

[69] Zillman, C. The Fortune 500 has more female CEOs than ever before. Fortune (2019). URL https: / / fortune.com/2019/ 05/16/fortune-500-female-ceos/. Accessed June 2020.

[70] Fuhrmans, V. Where are all the women CEOs? Wall Street Journal (2020). URL https://www.wsj.com/articles/ why-so-few-ceos-are-women-you-can-have-a-seatat-the-table-and-not-be-a-player-11581003276. Accessed June 2020.

[71] Sanofi. Development opportunity: Empowering your career (2020). URL https://www.sanofi.com/en/careers/ grow-with-us/development-opportunity-howsanofi-empowers-you. Accessed June 2020.

[72] Ferrante, M. B. Before breaking the glass ceiling, women must climb the maternal wall. Forbes (2018). URL https: //www. forbes.com/sites/marybethferrante/2018/ 10/31/before-breaking-the-glass-ceiling-womenmust-climb-the-maternal-wall/\#40fa4b89c519. Accessed June 2020.

[73] Pruchno, R., Litchfield, L. \& Fried, M. Measuring the impact of workplace flexibility. Tech. Rep., Chestnut Hill, Mass.: Boston College Center for Work \& Family, Carroll School of Management (2000).

[74] Gender-Equality Index. Bloomberg (2020). URL https : / /www . bloomberg. com/gei. Accessed June 2020.

[75] Gender reporting framework. Bloomberg (2019). URL https: //www.bloomberg.com/gei/framework/. Accessed June 2020.

[76] Anker, M. Addressing sex and gender in epidemic-prone infectious diseases. World Health Organization (2007). URL https://www. who.int/csr/resources/publications/ SexGenderInfectDis.pdf. Accessed June 2020.

[77] COVID-19 sex disaggregated data tracker. Global Health 50/50 (2020). URL https://globalhealth5050.org/ covid19/sex-disaggregated-data-tracker/. Accessed June 2020.

[78] Wenham, C., Smith, J. \& Morgan, R. COVID-19: the gendered impacts of the outbreak. The Lancet 395, 846-848 (2020). https: //doi.org/10.1016/S0140-6736 (20) 30526-2.

[79] Ovseiko, P. V., Chapple, A., Edmunds, L. D. \& Ziebland, S. Advancing gender equality through the Athena SWAN Charter for Women in Science: an exploratory study of women's and men's perceptions. Health Research Policy and Systems 15, 12 (2017). https://doi.org/10.1186/s12961-017-0177-9.

[80] Munir, F. et al. Evaluating the effectiveness and impact of the Athena SWAN Charter. Advance HE (2014). URL https://www.ecu.ac.uk/wp-content/uploads/ external/evaluating-the-effectiveness-andimpact-of-the-athena-swan-charter.pdf. Accessed June 2020.
[81] Smith, K., Arlotta, P. \& Watt, F. Seven actionable strategies for advancing women in science, engineering, and medicine. Cell Stem Cell 16, 221-224 (2015). https : //doi .org/10.1016/ j.stem.2015.02.012.

[82] Beeler, W. H. et al. Institutional report cards for gender equality: Lessons learned from benchmarking efforts for women in STEM. Cell Stem Cell 25, 306-310 (2019). www. doi.org/10.1016/ j.stem.2019.08.010. 